\title{
KYPROS.
}

\section{EINE MONOGRAPHIE}

YON

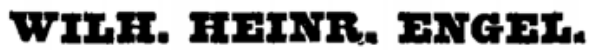

\section{ZWEITER THEIL.}

\author{
B E RLIN, \\ B E I G. R E I M E R. \\ 1841.
}


